\begin{abstract}
Reproductive parameters of the white anglerfish (Lophius piscatorius) in the northwestern Mediterranean Sea were studied in 556 specimens collected monthly aboard commercial fishing vessels that were trawling at depths of $12-836 \mathrm{~m}$. The main spawning season occurred from February through June. The size at maturity was estimated to be 48.8 $\mathrm{cm}$ in total length (TL) for males, $59.9 \mathrm{~cm}$ TL for females, and 51.3 cm TL for both sexes combined. The white anglerfish has group-synchronous oocyte development and determinate fecundity. It is a total spawner (spawns all its eggs once during a spawning season) and has a batch fecundity ranging from 661,647 to 885,214 oocytes, a relative batch fecundity of 66-128 oocytes per gram of female gutted weight, and a potential fecundity with values from 54,717 to 104,506 oocytes per kilogram of female total weight. This study is the first to provide the reproductive biology of white anglerfish in the northwestern Mediterranean Sea and provide valuable information that can be used to improve the stock assessment and ensure proper management of this species.
\end{abstract}

Manuscript submitted 2 November 2015. Manuscript accepted 21 October 2016.

Fish. Bull. 115:60-73 (2017).

Online publication date: 15 November 2016. doi: 10.7755/FB.115.1.6.

The views and opinions expressed or implied in this article are those of the author (or authors) and do not necessarily reflect the position of the National Marine Fisheries Service, NOAA.

\title{
Reproductive strategy of white anglerfish (Lophius piscatorius) in Mediterranean waters: implications for management
}

\author{
Ana I. Colmenero (contact author) \\ Víctor M. Tuset \\ Pilar Sánchez \\ Email address for contact author: colmenero@icm.csic.es \\ Institut de Ciències del Mar (ICM) \\ Consejo Superior de Investigaciones Científicas (CSIC) \\ Passeig Marítim de la Barceloneta 37-49 \\ 08003 Barcelona, Spain
}

The genus Lophius, commonly known as anglerfish, monkfish, or goosefish, belong to a family of bathydemersal fishes, which live and feed on the bottom of the seafloor generally below $200 \mathrm{~m}$ (Caruso, 1986). It includes 7 species distributed around the world. The white anglerfish (Lophius piscatorius) is found in the northeast Atlantic Ocean and the Mediterranean Sea, and the black anglerfish (Lophius budegassa) coexists with white anglerfish over most of its range, although the black anglerfish has a more southerly distribution in the Atlantic (Caruso, 1986). The shortspine African angler (Lophius vaillanti) is found in the eastern Atlantic (Maartens and Booth, 2005). The devil anglerfish (Lophius vomerinus) occupies the southeast Atlantic and the northern and western Indian Ocean (Walmsley et al., 2005). The blackfin goosefish (Lophius gastrophysus) inhabits the western Atlantic, and the goosefish (Lophius americanus) occurs in the northwest Atlantic (Caruso, 1983). Finally, the yellow goosefish (Lophius litulon) is distributed in the northwest Pacific, in the Gulf of Po-Hai, in the Yellow Sea, and in the East China Sea (Yoneda et al., 1997).

We focused on white anglerfish, which can be found on the continental shelf and slope, inhabiting depths from the shoreline to $>1000$ m (Afonso-Dias and Hislop, 1996). In the Mediterranean Sea, this species cohabits with black anglerfish, and even though the distributions of both species overlap, no ecological competition exists between them because of a temporal segregation in their daily biorhythms (Colmenero et al., 2010). Both of these species of Lophius play an important role in the trophic structure of benthodemersal ecosystems because they represent major predators, along with the European hake (Merluccius merluccius) (Díaz et al., 2008). In the community structure of the northwestern Mediterranean Sea, species of anglerfish are considered top predators (Coll et al., 2006; Valls et al., 2014). They are also reported to be important in the deepsea community (depths from $200 \mathrm{~m}$ to the bottom of the ocean) because they are the most abundant species (Labropoulou and Papaconstantinou, 2000; Maiorano et al., 2010).

Despite the fact that the deep sea is the largest ecosystem on the planet, is highly diverse, and has a wealth of resources, it is still mostly unknown and poorly understood in comparison with shallow-water ar- 
eas: therefore environmental management in deep waters is difficult (Ramirez-Llodra et al., 2010). In the last few decades, the decline of traditional fisheries on the continental shelf, the increasing demand for food sources, and rapid technological developments have resulted in an increasing exploitation of deep-sea resources (Koslow et al., 2000; Ramirez-Llodra et al., 2011) and in an incremental increase in the global mean depth of fishing (Watson and Morato, 2013).

This rise in deep-sea fishing has affected catches of Lophius species, given the growing demand for human consumption of this group of fish that is leading to an increase in worldwide commercial exploitation and targeting of anglerfishes (Fariña et al., 2008). Total catch reported globally for white anglerfish reached more than 26,500 metric tons (t) in 2014 (FAO Global Capture Production database, website) and total catch of anglerfishes in the northwestern Mediterranean Sea for the same year added up to 660 t (Tudó Vila ${ }^{1}$ ). Landings in our study area were composed primarily of black anglerfish (86\%) and generally only a small percentage of white anglerfish (14\%) (Tudó Vila $\left.{ }^{1}\right)$, but, for landings in Atlantic waters, the opposite is true; white anglerfish (94\%) dominate the catch (Dobby et al., 2008). Although the European Commission previously has conducted stock assessments of black anglerfish in the western Mediterranean Sea, there is no corresponding assessment for white anglerfish. The lack of information about the structure of the population of white anglerfish in this region and the lack of knowledge of the basic biology of this species are the main reasons for the absence of any assessment. The actual management regulations applied for black anglerfish generally are those applied to bottom trawling (European Union Council Regulation 1967/2006), with recommendations aimed at reducing the fishing effort of the fleet in order to avoid loss in stock productivity and decreases in landings (Cardinale et al. ${ }^{2}$ ).

The small quantity of white anglerfish available from landings in Mediterranean waters makes studies of this species challenging. Studies conducted in the Mediterranean Sea have been scarce, and they have been focused on temporal and spatial distribution of this species (Ungaro et al., 2002; Colmenero et al., 2010), age and growth (Tsimenidis and Ondrias, 1980; Tsimenidis, 1984), feeding ecology (López et al., 2016), morphometrics (Negzaoui-Garali and Ben Salem, 2008), parasites (Colmenero et al., 2015a), and ova characteristics (Colmenero et al., 2015b). Among these studies, only Ungaro et al. (2002) analyzed some of the biological features of this species by using data available from trawl surveys, including data on distribution, abun-

\footnotetext{
1 Tudó Vila, P. 2015. Unpubl. data. Directorate of Fishing and Maritime Affairs, Government of Catalonia, Avinguda Diagonal 523-525, 08029 Barcelona, Spain.

2 Cardinale, M., D. Damalas, and C. G. Osio (eds.). 2015. Scientific, Technical and Economic Committee for Fisheries (STECF)-Mediterranean Assessments, part 2 (STECF-1506), 396 p. Publications Office of the European Union, Luxembourg. [Available from website.]
}

dance, stock demography, and size at maturity. The latter work is valuable but is limited because sampling occurred only in the spring and summer; a whole year of sampling is recommended to obtain more accurate biological information.

A study of reproductive ecology is important for an understanding of population dynamics, and it is critical for assessing the effects of harvesting on fish populations when attempting to develop appropriate management strategies. Recruitment is recognized as a key process for maintaining sustainable populations, and the relationship between the reproductive output of the population and the resulting recruitment is central to understanding how a fish population will respond to constant stressors such as fishing (Chambers and Trippel, 1997). Although knowing more about the relationships between life history strategies and productivity with depth could help managers understand the potential response of a deep-sea species to fishing (Drazen and Haedrich, 2012), it is first necessary to conduct biological studies of fish to gain knowledge of the reproductive system of a species (Koslow et al., 1995). Such studies include gonad morphology (external and cellular description of the ovary and testis), reproductive pattern (hermaphroditism or gonochorism), reproductive behavior, reproductive cycle, spawning season duration, size at maturity, sex ratio, size at sexual transition, and fecundity.

All of this information can be applied at the population level to evaluate reproductive potential and to serve as a basis for limits on fishing that aim in order to keep recruitment at sustainable levels (GarcíaDíaz et al., 2006). Because reproductive strategy varies within species, depending on the area of distribution of each species and the depth distribution of each species in each area (Rotllant et al., 2002), there is a need for knowledge about reproduction of deep-sea fish species. Such information is needed particularly in the Mediterranean Sea because the data available for this region are limited (Morales-Nin et al., 1996; D'Onghia et al., 2008; Muñoz et al., 2010; Bustos-Salvador et al., 2015), and, furthermore, target species of fisheries have been the focus of only a few studies (Rotllant et al., 2002; Recasens et al., 2008).

The goal of this study was to describe the reproductive parameters-gonadal morphology, spawning season, size at sexual maturity, oocyte development, and fecundity-of white anglerfish in the northwestern Mediterranean Sea in order to provide valuable information and scientific background to improve stock assessments and effective management for Lophius species in Mediterranean waters.

\section{Materials and methods}

\section{Sampling and data collection}

Between June 2007 and December 2010, 556 white anglerfish, with total lengths (TLs) of 9-120 cm, were 


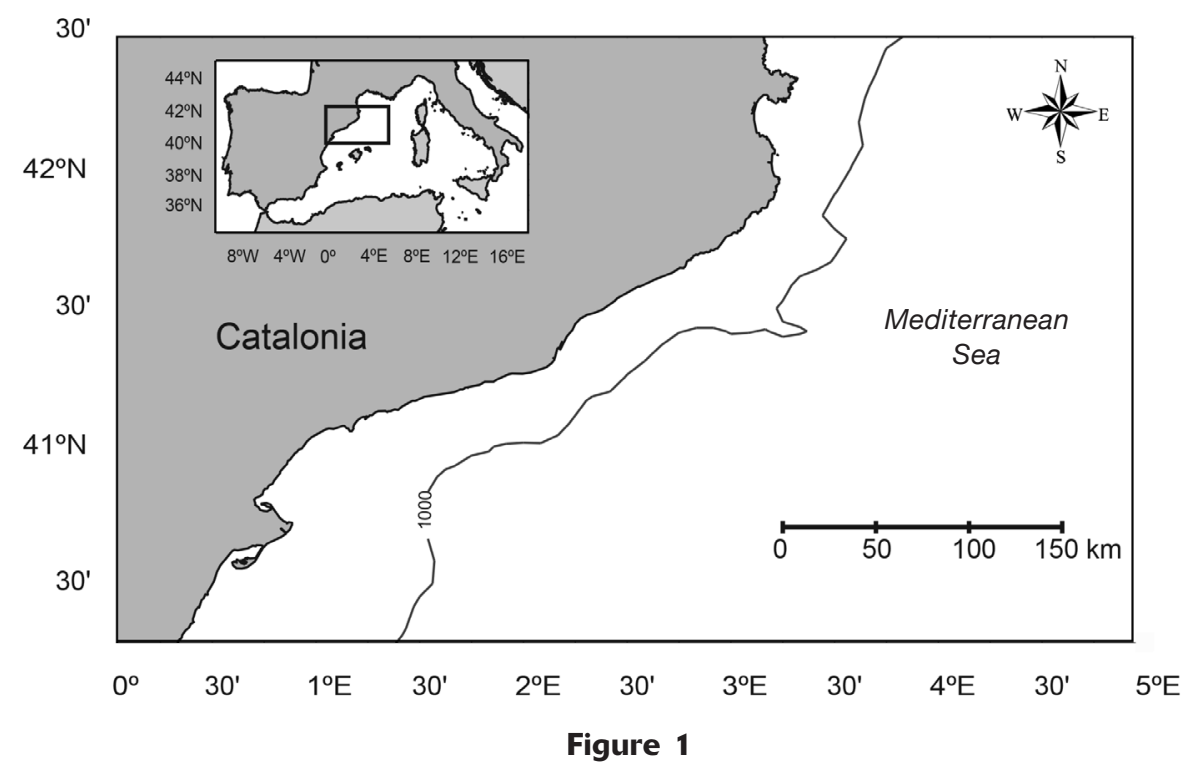

Map of the northwestern Mediterranean Sea showing the study area where white anglerfish (Lophius piscatorius) were collected from fishing grounds off the Catalan coast between June 2007 and December 2010.

collected monthly aboard commercial fishing vessels that were trawling at depths of 12-836 m. Fish were sampled from 467 stations located in the fishing grounds off the Catalan coast in the northwestern Mediterranean Sea from $40^{\circ} 5.980^{\prime} \mathrm{N}$ to $43^{\circ} 39.310^{\prime} \mathrm{N}$ and from $0^{\circ} 32.922^{\prime} \mathrm{E}$ to $3^{\circ} 35.718^{\prime} \mathrm{E}$ (Fig. 1). For each individual, TL was measured to the nearest centimeter, total weight (TW) and gutted weight (GW) were measured to the nearest gram, and gonad weight (GNW) and liver weight (LW) were measured to the nearest $0.01 \mathrm{~g}$. The sex of all fish was determined and assigned macroscopically to a gonadal stage on the basis of a scale of 5 maturity phases proposed by Colmenero et al. (2013): immature (phase I), developing or regenerating (phase II), spawning capable (phase III), actively spawning (phase IV), and regressing (phase V).

Fish that were too small $(<20 \mathrm{~cm}$ TL) for their sex to be determined or for assignment to a gonadal phase were classified as indeterminate. Macroscopic gonadal stage was validated histologically, according to the most advanced cell within the gonad (West, 1990). Gonads were fixed in $10 \%$ buffered formalin solution, dehydrated in ascending solutions of alcohols and embedded in a methacrylate polymer resin, sectioned at a thickness of $4 \mu \mathrm{m}$ with a manual microtome Leica Reichert-Jung $2040^{3}$ (Leica Microsystems, Wetzlar, Germany), stained with Lee's stain (methylene blue and basic fuchsin), and mounted in a synthetic resin of dibutyl phthalate xylene on microscope slides. Gonads were classified according to their size and color and the presence or absence of specific inclusions (oil droplets,

\footnotetext{
${ }^{3}$ Mention of trade names or commercial companies is for identification purposes only and does not imply endorsement by the National Marine Fisheries Service, NOAA.
}

yolk, postovulatory follicles, or sperm), as well as the type of oocytes (Wallace and Selman, 1981).

\section{Reproductive biology}

The spawning season was estimated by analyzing the monthly variation in the percentage of maturity phases and the changes in gonadosomatic index (GSI) and hepatosomatic index (HSI) for mature fish of each sex (Afonso-Dias and Hislop, 1996; Colmenero et al., 2013). Because indeterminate individuals $(n=27)$ were not considered, 251 males and 278 females were used to determine both indices, which were calculated according to Yoneda et al. (2001) as

$$
G S I=(G N W / G W) \times 100
$$

and

$$
H S I=(L W / G W) \times 100 .
$$

The lengths at which $25 \%, 50 \%$, and $75 \%$ of sampled fish reached sexual maturity were estimated by fitting the proportion of sexually mature males and females (phase III, phase IV, or phase V) and for both sexes combined to the logistic equation (Colmenero et al., 2013):

$$
P=100 /(1+\exp [a+b T L])
$$

where $P=$ the percentage of mature individuals as a function of size class (measured in TL); and

$a$ and $b$ are specific parameters that can change during the life cycle.

A logarithmic transformation was applied to this equation to calculate the parameters $a$ and $b$ by means of linear regression. 


\section{Oocyte development and fecundity}

Oocyte diameters obtained from 21 randomly selected specimens at all phases of maturity were measured to the nearest $0.01 \mu \mathrm{m}$ with an image analysis program (Image-Pro Plus, vers. 5.0, Media Cybernetics, Inc., Rockville, MD) in combination with an Axioskop 2 Plus microscope (Carl Zeiss Microscopy, LLC, Thornwood, NY), and a ProgRes C14 digital microscope camera (Jenoptik AG, Jena, Germany). Only oocytes sectioned through the nucleus were taken into account. The developmental stages of the oocytes were categorized according to the descriptions in Colmenero et al. (2013) that were adapted from Wallace and Selman (1981). The mean oocyte diameter by developmental stage was determined by calculating the diameter of all oocytes encountered in each subsample, and the range was set with the smallest and largest oocytes found at each developmental oocyte stage.

Fecundity was determined by using the gravimetric method described by Hunter and Goldberg (1980). Because homogeneity in oocyte distribution within ovaries of white anglerfish has already been established (Afonso-Dias and Hislop, 1996), ovarian tissue subsamples of approximately $500 \mathrm{mg}$ were taken randomly from 2 specimens with ovaries in phase III that had neither postovulatory follicles nor atretic oocytes present. Whole tissue subsamples were placed on several slides and covered with cover slips, then photographed with a Canon Powershot SD870 IS digital camera (Canon USA, Melville, NY). Oocytes were counted manually with Image-Pro Plus.

Batch fecundity $(\mathrm{BF})$, the total number of hydrated oocytes produced in a single spawning event by an individual female, of each female was determined by means of this equation:

$$
B F=\text { (oocyte number / sampled GNW) } \times \text { total GNW, }
$$

where $B F$ is the product of the number of secondary vitellogenic oocytes per unit of weight multiplied by the total ovarian weight (Yoneda et al., 2001). Relative batch fecundity (RBF), the total number of mature eggs released by a female during the spawning batch per gram of female GW, was calculated with the following equation (Pavlov et al., 2009):

$$
R B F=B F / G W .
$$

Potential fecundity was calculated as the number of vitellogenic oocytes divided by TW in kilograms for each mature female and then averaged (Murua et al., 2003).

\section{Results}

\section{Gonad morphology}

The gonad of female white anglerfish has 2 ribbon-like ovarian lobes connected to each other at their posterior end. One side of the "ribbon" consists of an ovigerous membrane from which a single layer of oocyte clusters, which contain oocytes at different developmental stages, projects into the lumen. The other side is nonovigerous and secretes a gelatinous material during maturation that fills the ovarian lumen, where mature oocytes develop (Fig. 2). During maturation, the gonad increases in size until it fills the abdominal cavity (Fig. 3 ). Testes are a pair of elongated organs with a bean shape in transverse section. Spermatogenesis takes place in a capsule-like sac called a cyst, but it is completed in the lumina of the lobules. The cysts appear to be arranged with a gradient of germ cells of increasing maturation from the cortex to the sperm duct (Fig. 4).

\section{Spawning season}

The monthly distribution of maturity phases (Fig. 5) revealed a peak in reproduction during spring, when a major portion of the spawning females and the highest value of GSI (0.77) were found. Spawning capable females (phase III) were caught primarily between April and June, and females in the actively spawning phase (IV) were observed in November, December, and March-the latter month having the maximum occurrence $(11 \%)$. Females in immature, regressing, and developing or regenerating phases (I, V, and II, respectively) were found year-round, although the highest percentage of immature individuals (49\%) was observed in January. The GSI values followed the same pattern shown in these maturity phases: highest during spring, decreasing during summer and autumn, and increasing again during winter. Males in all maturity phases were observed throughout the year, but with a maximum percentage of mature males $(66 \%)$ in February and March. Immature males were found primarily in July (69\%). The mean GSI for females increased as their ovaries developed and peaked in phase IV. For males, the mean GSI increased with testicular development and reached a maximum in phase IV (Table 1). The mean HSI for females and males increased during the summer and autumn months and decreased during winter and spring. On the basis of these observations, a main spawning season was found from February through June and a secondary one occurred in November and December.

\section{Size at sexual maturity}

The maturity ogive for males indicates that the length at which $50 \%$ of them reached sexual maturity $\left(L_{50}\right)$ was $48.4 \mathrm{~cm}$ TL (Fig. 6A). Maturity in males occurred at about $37 \%$ of their maximum observed TL. The smallest mature male found was $32.5 \mathrm{~cm}$ TL, and the largest immature male was $50 \mathrm{~cm}$ TL. The maturity ogive for females indicates that $L_{50}$ was $59.9 \mathrm{~cm}$ TL (Fig. 6B). Female maturity occurs at about $30 \%$ of their maximum observed TL. Like the smallest male, the smallest mature female was $32.5 \mathrm{~cm}$ TL. The largest immature female measured $56 \mathrm{~cm}$ TL. The maturity ogive for the sexes combined indicates an $L_{50}$ of 51.3 

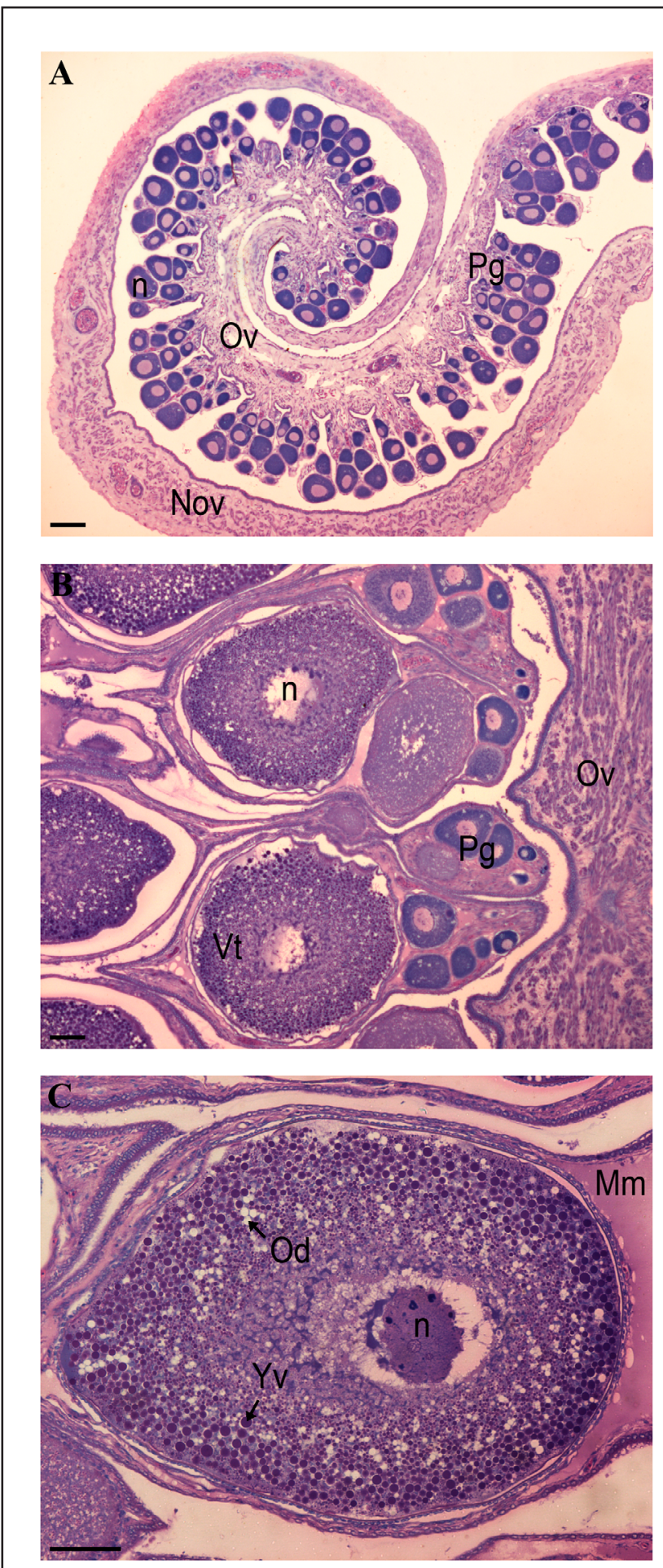

Figure 2

Histological sections from ovaries of female white anglerfish (Lophius piscatorius) in 3 phases of maturity: (A) immature, (B) spawning capable, and (C) actively spawning. $\mathrm{Ov}=$ ovigerous membrane, Nov=nonovigerous membrane, $\mathrm{n}=$ nucleus, $\mathrm{Pg}=$ primary growth stage, $\mathrm{Vt}=$ vitellogenesis stage, $\mathrm{Od}=0 \mathrm{il}$ droplet, $\mathrm{Yv}=$ yolk vesicle, $\mathrm{Mm}=$ mucus matrix. Scale bars $=100 \mu \mathrm{m}$. cm TL. The lengths at which $25 \%$ and $75 \%$ of fish attained maturity were 43.5 and $53.4 \mathrm{~cm}$ TL for males, 48.6 and $71.1 \mathrm{~cm} \mathrm{TL}$ for females, and 44.7 and $58 \mathrm{~cm}$ TL for the sexes combined.

\section{Oocyte development and fecundity}

Oocytes in different developmental stages were found in each maturity phase. They were organized in clusters where a gradient in the size of the oocyte was observed. A group of oocytes differentiated from others as the ovaries developed, indicating that white anglerfish has group-synchronous oocyte development and can be considered to have determinate fecundity (Fig. 7). Ovaries at each maturity phase contained primary oogoniaand perinucleolar-stage oocytes. Chromatin nucleolar were difficult to find and were present only in immature phase. Females at the cortical alveolar stage were not found in our samples. Vitellogenic and hydrated oocytes were located in females capable of spawning. Oocyte diameters at each stage of oocyte development are shown in Table 2.

Batch fecundity ranged from 661,647 to 885,214 oocytes from 2 females that measured 76 and $105 \mathrm{~cm}$ TL, 6331 and $16,178 \mathrm{~g}$ TW, and 5182 and $13,330 \mathrm{~g}$ GW, respectively. Relative batch fecundity ranged from 66 to 128 oocytes/g GW (average of 97 oocytes/g GW [standard deviation, SD 43]). Potential fecundity values moved from 54,717 to 104,506 oocytes/kg TW with a mean of 79,612 oocytes/kg TW (SD 35,206).

\section{Discussion}

Relevance of reproductive traits for sustainable management

Fishing activity during spawning seasons may affect population parameters, specifically composition of the size distribution, mortality rate, sexual structure of the population, size at maturity, and changes in the spawning season. These parameters, in turn, can increase the risk of over-exploitation of a stock.

Fishing during spawning periods may result in targeting a specific size class of the population and thus increasing the chance of catching the older (and larger) age classes and making the stock vulnerable to reproductive collapse (van Overzee and Rijnsdorp, 2015). Because spawning is generally limited to specific areas and times (Cushing, 1990), the conservation of resources can be enhanced by limiting fishing activity in a spatiotemporal frame. Furthermore, fishing pressure has been documented to have reduced initial size at maturity - an issue that is a concern particularly for late-maturing species (Stewart et al., 2010). If size of capture is below the size at first maturity, there is a genuine risk of recruitment overfishing. Therefore, knowledge of the spawning season and the size at maturity can help managers establish closed seasons and prevent fishing at this vulnerable time in the life cycle 


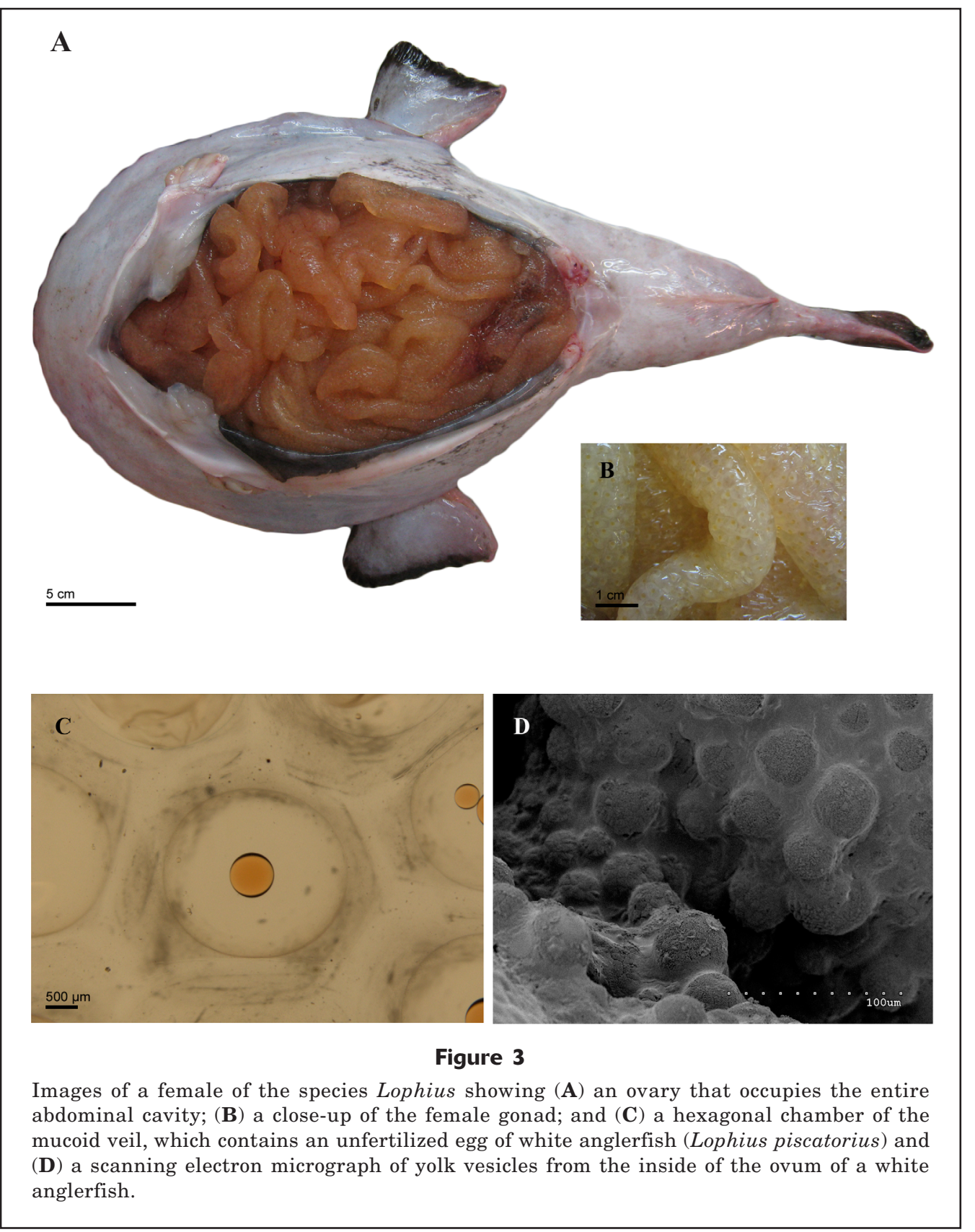

of fish species by preserving breeding individuals and establishing a legal minimum size.

The results of our study of white anglerfish in the northwestern Mediterranean Sea indicate that a long spawning period occurs during mid-winter and late spring, from February through June, although a secondary breeding period has been observed in November and December. These results agree with those obtained in studies that were focused on the northeastern Atlantic Ocean, where this species spawns from November through June (Fulton, 1898; Afonso-Dias and Hislop, 1996; Hislop et al., 2001). However, a previous study in the northwestern Mediterranean Sea identified a spawning season during spring-summer (Ungaro et al., 2002). Discrepancies between the latter study and our work may be explained by the differences in sampling periods.

Nevertheless, spawning seasonality, which is associated with environmental conditions and local oceanographic features, varies between species as well as by geographical area. An example of this variability in spawning seasonality can be observed in 2 locations along the Atlantic-Iberian coast: on the Portuguese and western Spanish coasts, spawning of the white anglerfish takes place during winter-spring (Duarte et al., 2001), whereas on the northern Spanish coast (Bay 


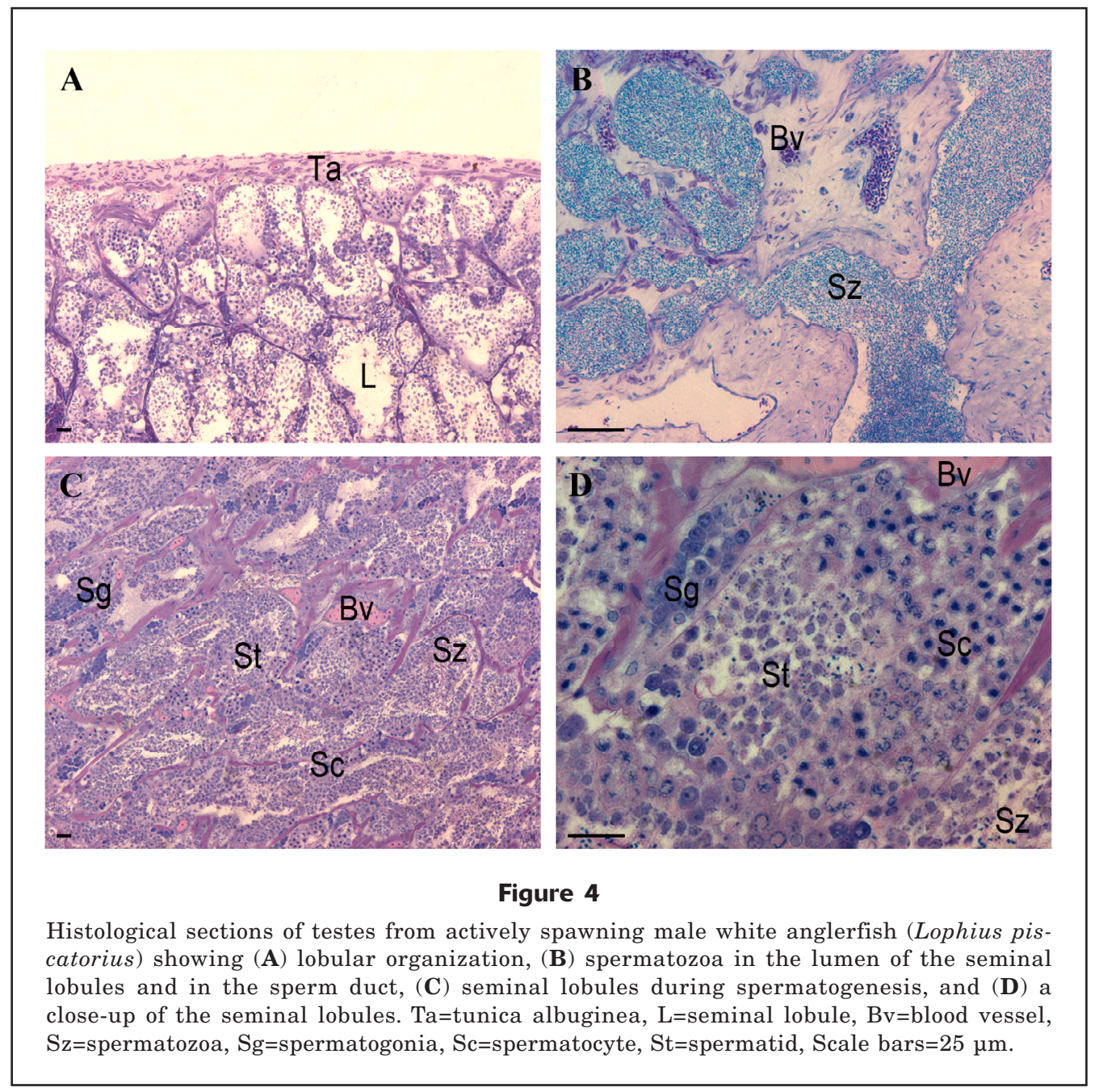

of Biscay), spawning occurs during summer (Quincoces et $a .^{4}$ ). In fact, spawning activity for one of its congenerics, the black anglerfish, in the northwestern Mediterranean seems to occur from November through March and a secondary spawning occurs in August and September (Colmenero et al., 2013). Although a little overlap exists between spawning seasons of both of these Lophius species in Mediterranean waters, the main period is markedly different, and that difference lessens competition among these species.

Usually, species of Lophius have long spawning periods ranging between 4 and 6 months. Black anglerfish off the Spanish-Atlantic coasts spawn from November through February (Duarte et al., 2001), and in the Bay of Biscay the peak spawning period is from May through July (Quincoces et al. ${ }^{5}$ ). The goosefish off the

\footnotetext{
${ }^{4}$ Quincoces, I., M. Santurtún, and P. Lucio. 1998. Biological aspects of white anglerfish (Lophius piscatorius) in the Bay of Biscay (ICES Division VIIIa, b, d), in 1996-1997. ICES Council Meeting (C.M.) Documents 1998/O:48, 29 p.

${ }^{5}$ Quincoces, I., P. Lucio, and M. Santurtún. 1998. Biology of black anglerfish Lophius budegassa in the Bay of Biscay
}

East Coast of the United States has its reproductive period from May through June (Armstrong et al., 1992), spawning for the blackfin goosefish off the Brazilian coasts takes place during spring and summer (Valentim et al., 2007), and the yellow goosefish spawns between February and May in the East China Sea and the Yellow Sea (Yoneda et al., 2001). The devil anglerfish off the coast of South Africa has a well-defined summer breeding season (Griffiths and Hecht, 1986), and individuals of this species off the coast of Namibia spawn throughout the year with a slight increase between autumn and spring (Maartens and Booth, 2005).

Most deep-sea fish species reach sexual maturity at sizes larger than those of species that inhabit the continental shelf reach maturity, and, in some cases, males mature at smaller sizes than females (Rotllant et al., 2002; Pajuelo et al., 2008). A similar pattern was observed for white anglerfish-one in which females mature sexually at larger sizes $(59.9 \mathrm{~cm}$ TL $)$ than those recorded for males $(48.4 \mathrm{~cm}$ TL). This pattern has also

waters, during 1996-1997. ICES Council Meeting (C.M.) Documents 1998/O:47, 28 p. 


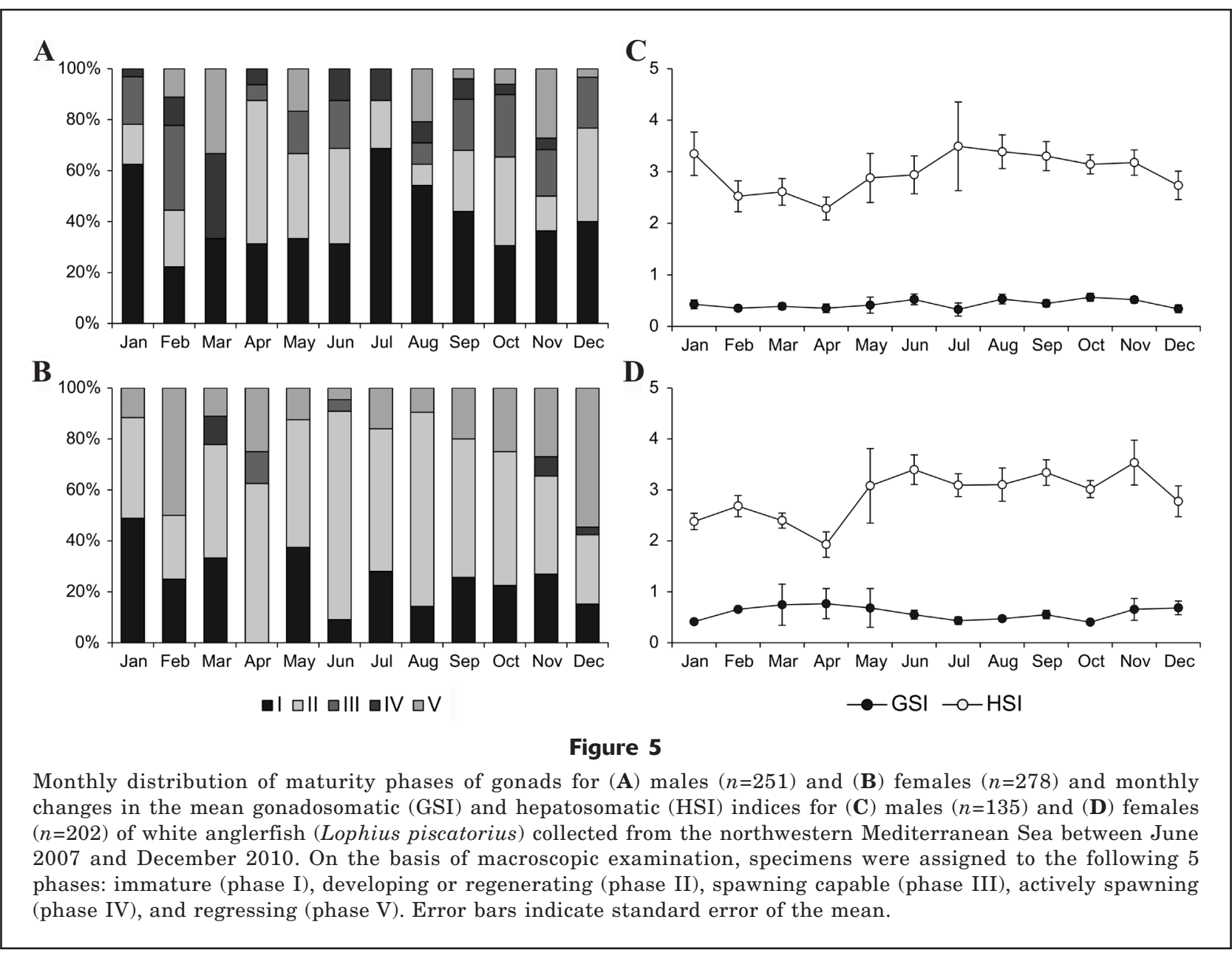

been found for white anglerfish in other areas (Ofstad and Laurenson ${ }^{6}$ ) and for other species of anglerfish. Female black anglerfish, for example, mature at $48.2 \mathrm{~cm}$ TL, whereas males attain first maturity at $33.4 \mathrm{~cm}$ TL (Colmenero et al., 2013), and female devil anglerfish reach sexual maturity at $58.2 \mathrm{~cm}$ TL, whereas males of this species mature at $39.9 \mathrm{~cm}$ TL (Maartens and Booth, 2005). For the goosefish, $L_{50}$ for females and males was estimated at 48.5 and $36.9 \mathrm{~cm}$ TL, respectively (Armstrong et al., 1992), and female yellow goosefish mature at $56.7 \mathrm{~cm} \mathrm{TL}$ and males of this species mature at 36.2 $\mathrm{cm}$ (Yoneda et al., 2001). This dissimilarity in size at maturity is usually associated with a trade-off between life history traits, where early maturity involves a larger size but a slower growth (Stearns and Koella, 1986; Charnov, 2008).

\section{Reproductive strategy}

The reproductive strategy of white anglerfish is one of discontinuous oogenesis with synchronous development

\footnotetext{
${ }^{6}$ Ofstad, L. H., and C. Laurenson. 2007. Biology of anglerfish Lophius piscatorius in Faroese waters. ICES Council Meeting (C.M.) Documents 2007/K:07, 16 p.
}

of vitellogenic oocytes and is, therefore, this species is considered a total spawner (Afonso-Dias and Hislop, 1996). The oocytes ovulate at once, and the eggs are released in either a unique event or over a short period of time, as part of a single episode during the spawning season (Murua and Saborido-Rey, 2003; Pavlov et al., 2009). This pattern of oocyte development and spawning patterns is also found in other species of Lophius (Leslie and Grant, 1990; Armstrong et al., 1992; Colmenero et al., 2013). Yoneda et al. (2001) suggested that yellow goosefish may have the potential to spawn more than once a year, on the basis of the observation of a captive specimen that released several infertile egg masses. However, this spawning behavior cannot be considered normal.

Female anglerfish spawn their eggs in a mucoid veil that floats near the surface. The veil consists of individual chambers that contain 1-3 eggs and has an opening that provides water circulation. In our study, we recognized in some chambers the presence of 2 eggs sharing the same chamber. Although this way of releasing eggs is not common among fish species, some Scorpaeniformes, such as the shortfin turkeyfish (Dendrochirus brachypterus) (Fishelson, 1978) or the short- 


\section{Table 1}

Gonadosomatic (GSI) and hepatosomatic (HSI) indices at each maturity phase for male and female white anglerfish (Lophius piscatorius) collected from the northwestern Mediterranean Sea between June 2007 and December 2010. SE=standard error.

\begin{tabular}{|c|c|c|c|c|c|c|}
\hline Sex & Maturity phase & GSI range & Mean GSI (SE) & HSI range & Mean HSI (SE) & $n$ \\
\hline \multirow[t]{5}{*}{ Male } & I & $0.01-0.41$ & $0.10(0.01)$ & $1.04-4.65$ & $2.37(0.07)$ & 106 \\
\hline & II & $0.06-1.07$ & $0.25(0.03)$ & $0.27-5.11$ & $2.67(0.14)$ & 54 \\
\hline & III & $0.21-1.30$ & $0.61(0.05)$ & $1.92-6.72$ & $3.20(0.18)$ & 35 \\
\hline & IV & $0.30-1.70$ & $0.70(0.09)$ & $0.40-5.39$ & $3.34(0.28)$ & 17 \\
\hline & $\mathrm{V}$ & $0.19-1.11$ & $0.50(0.06)$ & $2.04-5.10$ & $3.35(0.22)$ & 17 \\
\hline \multirow[t]{5}{*}{ Female } & I & $0.01-0.86$ & $0.23(0.02)$ & $0.92-5.33$ & $2.37(0.11)$ & 66 \\
\hline & II & $0.04-1.22$ & $0.40(0.02)$ & $0.42-7.79$ & $2.87(0.10)$ & 133 \\
\hline & III & $0.61-1.65$ & $1.13(0.52)$ & $2.15-5.83$ & $3.99(1.85)$ & 2 \\
\hline & IV & $1.59-3.86$ & $2.81(0.52)$ & $2.68-8.50$ & $5.80(1.20)$ & 4 \\
\hline & $\mathrm{V}$ & $0.18-2.44$ & $0.66(0.06)$ & $0.36-8.59$ & $3.03(0.17)$ & 60 \\
\hline
\end{tabular}

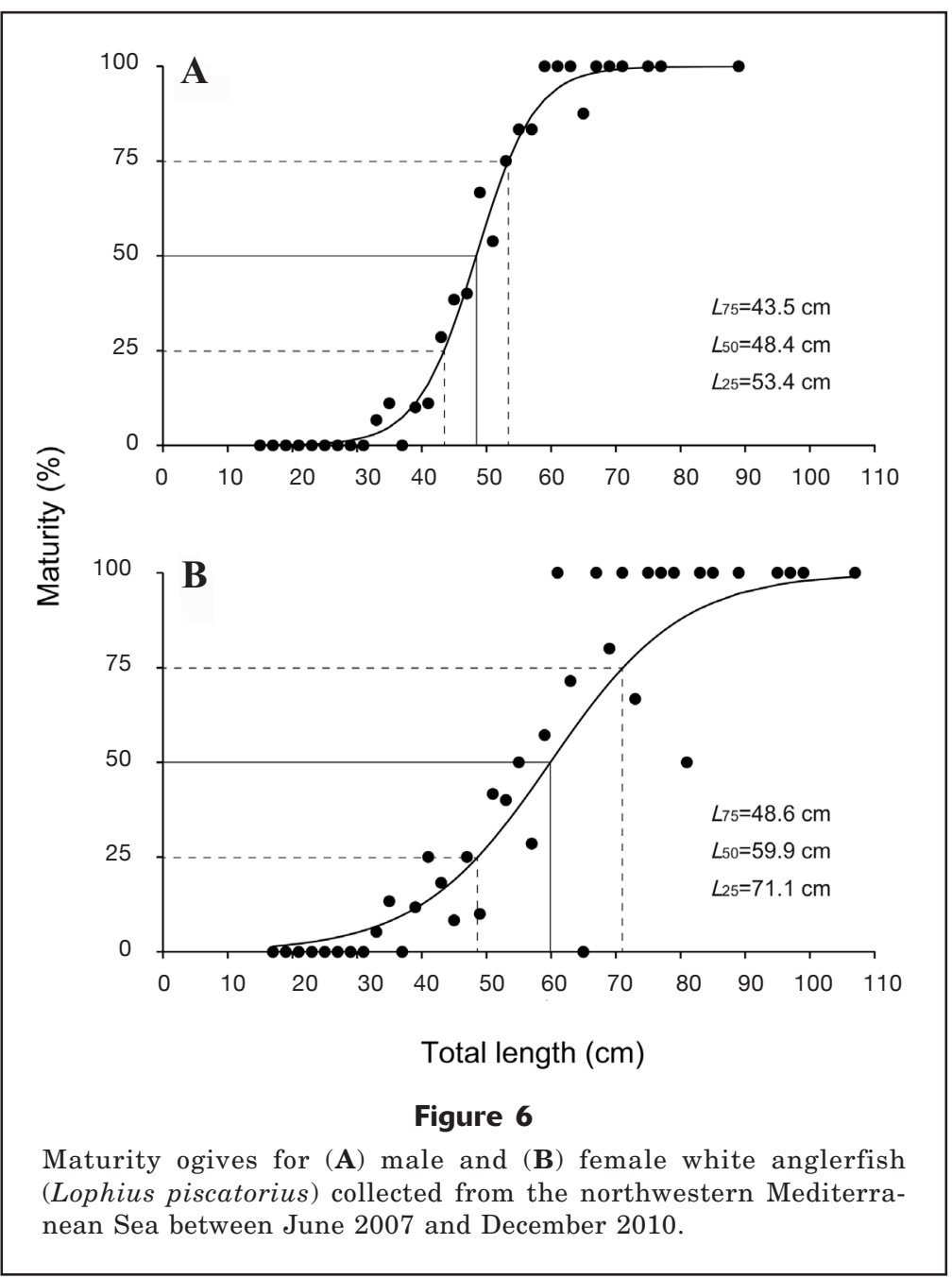

spine thornyhead (Sebastolobus alascanus) (Erickson and Pikitch, 1993), also spawn buoyant gelatinous egg masses. It has been proposed that the advantages of releasing eggs in these veils facilitate their dispersal; the egg veil floats near the surface and is subject to the actions of wind, currents, and waves. The veil also serves as protection for eggs against predation because of the presence of obnoxious or toxic substances in the veils (Armstrong et al., 1992). Moreover, the veil may help with the fertilization of eggs. When males are present and the egg ribbon is laid, the ribbon keeps the eggs together and prevents their dispersion through the water. The males then eject milt near the veil to guarantee fertilization of all the eggs (Dahlgren, 1928). Armstrong et al. (1992) suggested that sperm reach oocyte chambers through the pores that connect the chambers when the ribbon is extruded from the female and starts to absorb water.

Another feature of the reproduction of the white anglerfish to highlight is its type of spermatogenesis, which is known to be semicystic. Spermatogenesis starts inside the cysts that contain germinal cells in different stages of development from spermatogonia to spermatids, but it is not completed within the cyst. During spermatogenesis, the cyst breaks and spermatids are released from the cyst into the lumen of the lobule, where they become spermatozoa. This kind of spermatogenesis has been described previously in the family Lophiidae only in the blackmouth angler (Lophiomus setigerus) (Yoneda et al., 1998) and in black anglerfish 
Table 2

Oocyte diameters, ranges and means with standard errors (SEs), and histological characteristics of ovarian follicles in white anglerfish (Lophius piscatorius), collected from the northwestern Mediterranean Sea between June 2007 and December 2010. $\mathrm{SE}=$ standard error, at each stage of oocyte development.

\begin{tabular}{|c|c|c|c|}
\hline $\begin{array}{l}\text { Stages of } \\
\text { oocyte development }\end{array}$ & $\begin{array}{c}\text { Mean oocyte } \\
\text { diameter }(\mu \mathrm{m})(\mathrm{SE})\end{array}$ & $\begin{array}{l}\text { Oocyte diameter } \\
(\mu \mathrm{m}) \text { range }\end{array}$ & Histological characteristics \\
\hline Primary growth stage & $82.79(2.34)$ & $12-203$ & $\begin{array}{l}\text { Nucleus contains a large nucleolus and some } \\
\text { peripheral nucleoli. Yolk granules are not pres- } \\
\text { ent in the cytoplasm. }\end{array}$ \\
\hline Cortical alveolar stage & $256.10(3.08)$ & $207-316$ & $\begin{array}{l}\text { Cortical alveolar vesicles and oil droplets appear } \\
\text { in the cytoplasm. Yolk granules are not yet pres- } \\
\text { ent in the cytoplasm. Nucleus is central within } \\
\text { the yolk }\end{array}$ \\
\hline Vitellogenesis & $729.31(17.58)$ & $324-876$ & $\begin{array}{l}\text { Yolk granules appear between cortical alveolar } \\
\text { vesicles. As vitellogenesis advances, yolk gran- } \\
\text { ules fill the cytoplasm until they are in contact } \\
\text { with the nucleus, which remains in a central } \\
\text { position. }\end{array}$ \\
\hline Migratory nucleus & $939.31(7.77)$ & $902-1008$ & $\begin{array}{l}\text { Yolk granules and oil droplets start to fuse. } \\
\text { Nucleus migrates to one pole of the oocyte. }\end{array}$ \\
\hline Hydration & $1672.50(4.77)$ & $1523-1750$ & $\begin{array}{l}\text { Yolk granules form a single mass. Nucleus is not } \\
\text { present in the cytoplasm. }\end{array}$ \\
\hline
\end{tabular}

(Colmenero et al., 2013). This specialized spermatogenesis also has been found in other deep-sea species of Neoceratiidae (Jespersen, 1984) and of Macruridae (Fernandez-Arcaya et al., 2013), in the shore clingfish (Lepadogaster lepadogaster) (Mattei and Mattei, 1978), in species of Blennidae (Lahnsteiner and Patzner, 1990), in a species of Ophidion (Mattei et al., 1993), in the dusky jawfish (Opistognathus whitehursti) (Manni and Rasotto, 1997), and in species of Scorpaena (Muñoz et al., 2002; Sàbat et al., 2009), which also release their eggs in gelatinous substances.

\section{Fecundity}

Because of their particular reproduction behavior, which includes a high parental investment in the offspring, white anglerfish are likely to spawn once a year, and the population dynamics of this species are expected to be highly sensitive to external biological and ecosystem factors $\left(\mathrm{ICES}^{7}\right)$. Spawning occurs in deep waters because mature white anglerfish have been described by Hislop et al. (2001) as migrating to deeper water before spawning. The same behavior is seen in yellow goosefish: adult fish migrate to deeper waters in response to seasonal changes in water temperature and gonadal maturation (Yoneda et al., 2002).

\footnotetext{
${ }^{7}$ ICES (International Council for the Exploration of the Sea). 2012. Report of the working group on the assessment of southern shelf stocks of hake, monk and megrim (WGHMM), 10-16 May 2012, ICES Headquaters, Copenhagen, Denmark. ICES CM 2012/ACOM:11, 617 p.
}

These vertical migrations into deeper waters where commercial fishing and scientific surveys cannot reach could be the reason that very few mature females were captured during our study - a trend that is common in other studies of Lophius species (Ofstad and Laurenson $\left.^{6}\right)$. Clearly, this low number of mature females will affect the estimation of such reproductive parameters as fecundity.

Generally, deep-sea species have low fecundity and large egg sizes (Gage and Tyler, 1991; Herring, 2002). The white anglerfish has determinate fecundity with values between 661,647 to 885,214 oocytes-levels that are high in comparison with other deep-sea species that inhabit the same depth strata but that are similar to the mean potential fecundity of its Mediterranean congeneric, the black anglerfish (Colmenero et al., 2013). Fecundity values vary among populations as a result of adaptations to local environmental conditions, and they are related to abiotic factors, such as temperature and salinity (Nissling and Dahlman, 2010; Thorsen et al., 2010), and to biotic factors, such as food supply, population density, allocation of energy to reproduction, and fish size (Treasurer, 1981; Merrett, 1994; Nash et al., 2000).

In this study, we were not able to determine correlations between fecundity and these factors because only 2 actively spawning females were collected. Eggs of white anglerfish have been reported to have a mean diameter of $2.72 \mathrm{~mm}$ (SD 0.08) (Colmenero et al., $2015 b)$, a size that is considered large for pelagic eggs, which typically range from 0.5 to $5.5 \mathrm{~mm}$ in diameter (Ahlstrom and Moser, 1980). Larger eggs have more 


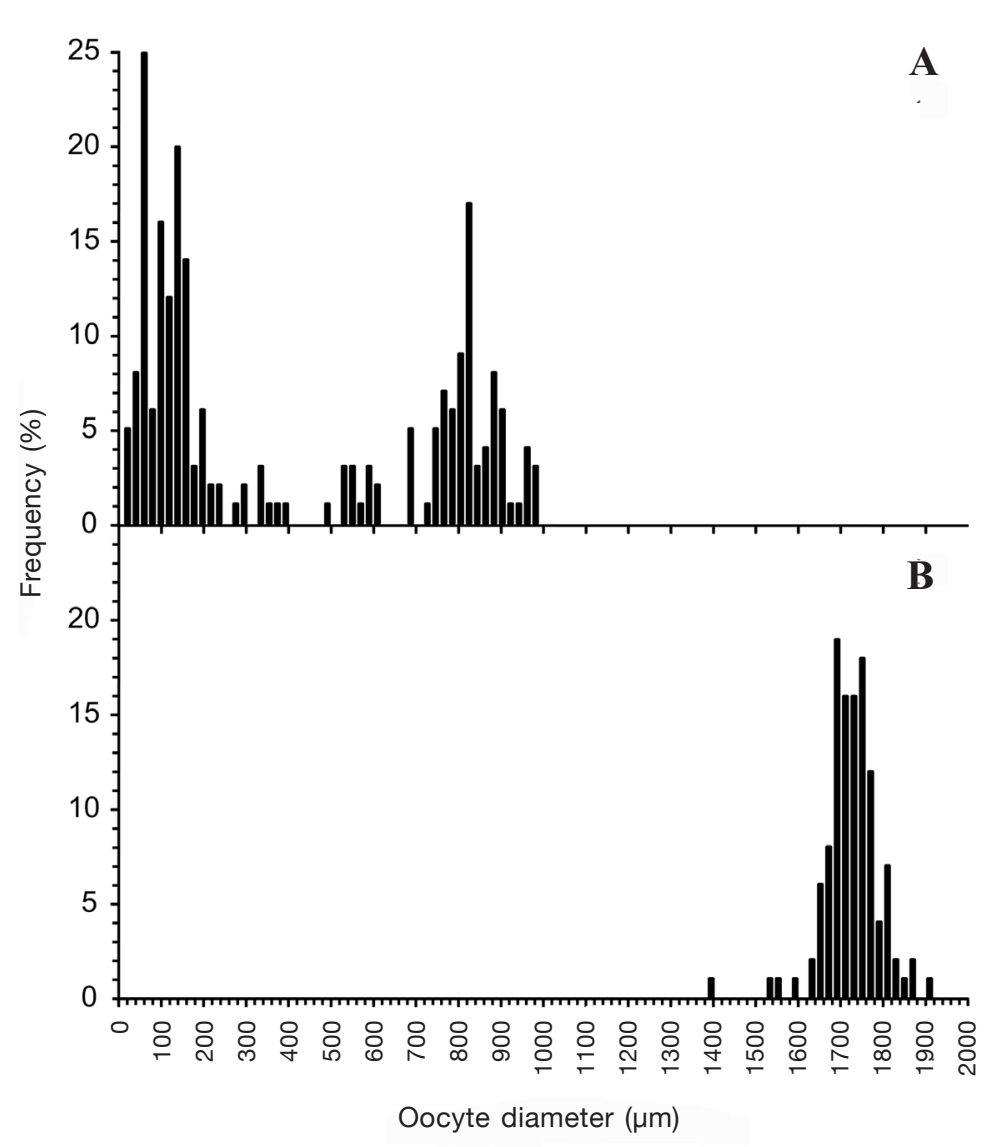

Figure 7

Distribution of oocyte diameters in (A) spawning capable and (B) actively spawning female white anglerfish (Lophius piscatorius) collected from the northwestern Mediterranean Sea between June 2007 and December 2010 .

where dissolved oxygen is low (Hendry and Day, 2003).

\section{General remarks}

In this study, we estimated the spawning season, size at sexual maturity, and fecundity of white anglerfish. Considering the parameter values that we obtained, we can conclude that this species is one that employs a $K$ reproductive strategy. In general, this strategy is defined by a large body size, longevity, late maturation, and low fecundity (Pianka, 1970, 1974). A wide range of deep-sea demersal fish species generally display life history characteristics consistent with $K$-selection (Adams, 1980; Gage and Tyler, 1991). These traits make deep-sea fish stocks highly vulnerable to fishing and capable of little resilience to over-exploitation, increasing the urgency for the conservation and management of this group of animals (Koslow et al., 2000; Morato et al., 2006; Norse et al., 2012).

Theoretically, the $K$-strategy for deepsea fish species should imply a low fecundity; however, some species, such as the North Pacific armorhead (Pseudopentaceros wheeleri), wreckfish (Polyprion americanus), and splendid alfonsino (Beryx splendens), have high fecundities (Sedberry et al., 1996; Lehodey et al., 1997; Humphreys, 2000). White angelfish and species of Lophius in general also should be included in this group because of their high fecundity (Afonso-Dias and Hislop,

yolk, which increases the potential for larval survival (Duarte and Alcaraz, 1989). The only information available about egg diameters for other species of Lophius is for yellow goosefish, which occupy a bathymetric range that is similar to that occupied by white anglerfish and have a similar egg size (Yoneda et al., 2001). In contrast, the black anglerfish has an egg diameter of 1.88 $\mathrm{mm}$ (SD 0.12), a size that is nearly 1.5 times smaller than the diameters reported for the white anglerfish and yellow goosefish, and inhabits shallower waters than those inhabited by the other 2 species (Colmenero et al., 2015b). A comparative study of egg sizes in deepsea species found that egg size increased significantly with depth (Fernandez-Arcaya ${ }^{8}$ ). Egg size is important to offspring survival in many organisms, and large eggs survive better than small ones in environments

\footnotetext{
${ }^{8}$ Fernandez-Arcaya, U. 2015. Personal commun. Departamento de Recursos Marinos Renovables, Institut de Ciències del Mar, Passeig Marítim de la Barceloneta, 37-49, 08003 Barcelona, Spain.
} 1996; Colmenero et al., 2013). This variability in reproductive strategy is the result of adaptation to environmental changes, such as temperature, bathymetric pressure, light, and food availability (Herring, 2002; Brown-Peterson et al., 2011). Likely, the high fecundity and the low economic value of the white anglerfish, at least until the last decades of the 20th century, has allowed the stock to be sustainable within acceptable limits. With the recent expansion of anglerfish fisheries, sustainability is in question, and our study is the first step toward an informed assessment of this deepsea resource and its management with an ecosystem perspective.

\section{Acknowledgments}

The authors would like to thank the crew of the fishing vessels Avi Pau, Estel-lada, Germans Félix, San Benito, and Port de Roses for allowing us to conduct sampling aboard their vessels. We also thank M. Baeta and L. 
Martínez for helping with data collection, A. Ospina for assisting with the map of the study area, and C. Barría, $\mathrm{N}$. Amat, and R. Alarcon for their valuable comments. We offer special thanks to K. Denning for revising the English of the early draft. This study was part of the project Monitoratge del recursos pesquers i marisquers al litoral català of the Directorate of Fishing and Maritime Affairs, Government of Catalonia.

\section{Literature cited}

Adams, P. B.

1980. Life history patterns in marine fishes and their consequences for fisheries management. Fish. Bull. 78:1-12.

Afonso-Dias, I. P., and J. R. G. Hislop.

1996. The reproduction of anglerfish Lophius piscatorius Linnaeus from the north-west coast of Scotland. J. Fish Biol. 49:18-39. Article

Ahlstrom, E. H., and H. G. Moser.

1980. Characters useful in identification of pelagic marine fish eggs. CalCOFI Rep. 21:121-131.

Armstrong, M. P., J. A. Musick, and J. A. Colvocoresses. 1992. Age, growth, and reproduction of the goosefish Lophius americanus (Pisces: Lophiiformes). Fish. Bull. 90:217-230.

Brown-Peterson, N. J., D. M. Wyanski, F. Saborido-Rey, B. J. Macewicz, and S. K. Lowerre-Barbieri.

2011. A standardized terminology for describing reproductive development in fishes. Mar. Coast. Fish. 3:52-70. Article

Bustos-Salvador, F., U. Fernandez-Arcaya, E. Ramirez-Llodra, J. Aguzzi, L. Recasens, and G. Rotllant.

2015. Reproductive biology of NW Mediterranean tonguefish Symphurus nigrescens and Symphurus ligulatus. J. Mar. Biol. Assoc. U.K. 95:1041-1049.

Caruso, J. H.

1983. The systematics and distribution of the lophiid anglerfishes: II. Revisions of the genera Lophiomus and Lophius. Copeia 1983:11-30. Article

1986. Lophiidae. In Fishes of the North-eastern Atlantic and the Mediterranean (P. J. P. Whitehead, M.-L. Bauchot, J.-C. Hureau, J. Nielsen, and E. Tortonese, eds.), p. 1362-1363. UNESCO, Paris.

Chambers, R. C., and E. A. Trippel (eds.).

1997. Early life history and recruitment in fish populations, 596 p. Chapman and Hall, London.

Charnov, E. L.

2008. Fish growth: Bertalanffy $k$ is proportional to reproductive effort. Environ. Biol. Fish. 83:185-187. Article

Colmenero, A. I., J. Aguzzi, A. Lombarte, and A. Bozzano. 2010. Sensory constraints in temporal segregation in two species of anglerfish, Lophius budegassa and L. piscatorius. Mar. Ecol. Prog. Ser. 416:255-265. Article

Colmenero, A. I., V. M. Tuset, L. Recasens, and P. Sánchez. 2013. Reproductive biology of Black Anglerfish (Lophius budegassa) in the northwestern Mediterranean Sea. Fish. Bull. 111:390-401. Article

Colmenero, A. I., C. Barría, S. W. Feist, and V. M. Tuset. 2015a. Observations on the occurrence of Spraguea lophii in Mediterranean lophiids. Parasitol. Res. 114: 1977-1983. Article
Colmenero, A. I., V. M. Tuset, J.-M. Fortuño, and P. Sánchez. 2015b. The chorion ultrastructure of ova of Lophius spp. J. Fish Biol. 86:1881-1886. Article

Coll, M., I. Palomera, S. Tudela, and F. Sardà.

2006. Trophic flows, ecosystem structure and fishing impacts in the South Catalan Sea, Northwestern Mediterranean. J. Mar. Syst. 59:63-96. Article

Cushing, D. H.

1990. Plankton production and year-class strength in fish populations: an update of the match/mismatch hypothesis. Adv. Mar. Biol. 26:249-293. Article

D’Onghia, G., P. Maiorano, and L. Sion.

2008. A review on the reproduction of grenadiers in the Mediterranean with new data on the gonad maturity and fecundity. Am. Fish. Soc. Symp. 63:169-184.

Dahlgren, U.

1928. The habits and life history of Lophius, the anglerfish. Nat. Hist. 28:18-32.

Díaz, P., J. Santos, F. Velasco, A. Serrano, and N. Pérez.

2008. Anglerfish discard estimates and patterns in Spanish Northeast Atlantic trawl fisheries. ICES J. Mar. Sci. 65:1350-1361. Article

Dobby, H., L. Allan, M. Harding, C. H. Laurenson, and H. A. McLay.

2008. Improving the quality of information on Scottish anglerfish fisheries: making use of fishers' data. ICES J. Mar. Sci. 65:1334-1345. Article

Drazen, J. C., and R. L. Haedrich.

2012. A continuum of life histories in deep-sea demersal fishes. Deep-Sea Res. Oceanogr., I 61:34-42. Article

Duarte, C. M., and M. Alcaraz.

1989. To produce many small or few large eggs: a sizeindependent reproductive tactic of fish. Oecologia 80:401-404. Article

Duarte, R., M. Azevedo, J. Landa, and P. Pereda.

2001. Reproduction of anglerfish (Lophius budegassa Spinola and Lophius piscatorius Linnaeus) from the Atlantic Iberian coast. Fish. Res. 51:349-361. Article

Erickson, D. L., and E. K. Pikitch.

1993. A histological description of shortspine thornyhead, Sebastolobus alascanus, ovaries: structures associated with the production of gelatinous egg masses. Environ. Biol. Fish. 36:273-282. Article

Fariña, A. C., M. Azevedo, J. Landa, R. Duarte, P. Sampedro, G. Costas, M. A. Torres, and L. Cañás.

2008. Lophius in the world: a synthesis on the common features and life strategies. ICES J. Mar. Sci. 65:1272-1280. Article

Fernandez-Arcaya, U., E. Ramirez-Llodra, G. Rotllant, L. Recasens, H. Murua, I. Quaggio-Grassiotto, and J. B. Company. 2013. Reproductive biology of two macrourid fish, Nezumia aequalis and Coelorinchus mediterraneus, inhabiting the NW Mediterranean continental margin (400-2000 m). Deep-Sea Res. Oceanogr., II 92:63-72. Article

Fishelson, L.

1978. Oogenesis and spawn-formation in the pigmy lion fish Dendrochirus brachypterus (Pteroidae). Mar. Biol. 46:341-348. Article

Fulton, T. W.

1898. The ovaries and ovarian eggs of the angler or frogfish (Lophius piscatorius), and of the John Dory (Zeus faber). Annu. Rep. Fish. Board Scotl. 16:125-134.

Gage, J. D., and P. A. Tyler.

1991. Deep-sea biology: a natural history of organisms at the deep-sea floor, 524 p. Cambridge Univ. Press, Cambridge, UK. 
García-Díaz, M., J. A. González, M. J. Lorente, and V. M. Tuset. 2006. Spawning season, maturity sizes, and fecundity in blacktail comber (Serranus atricauda) (Serranidae) from the eastern-central Atlantic. Fish. Bull. 104:159-166.

Griffiths, M. H., and J. Hecht.

1986. A preliminary study of age and growth of the monkfish Lophius upsicephalus (Pisces: Lophiidae) on the Agulhas Bank, South Africa. S. Afr. J. Mar. Sci. 4:51-60. Article

Hendry, A. P., and T. Day.

2003. Revisiting the positive correlation between female size and egg size. Evol. Ecol. Res. 5:421-429.

Herring, $\mathrm{P}$

2002. The biology of the deep ocean, 314 p. Oxford Univ. Press, Oxford.

Hislop, J. R. G., A. Gallego, M. R. Heath, F. M. Kennedy, S. A. Reeves, and P. J. Wright.

2001. A synthesis of the early life history of the anglerfish, Lophius piscatorius (Linnaeus, 1758) in northern British waters. ICES J. Mar. Sci. 58:70-86. Article

Humphreys, R. L, Jr.

2000. Otolith-based assessment of recruitment variation in a North Pacific seamount population of armorhead Pseudopentaceros wheeleri. Mar. Ecol. Prog. Ser. 204:213-223. Article

Hunter, J. R., and S. R. Goldberg.

1980. Spawning incidence and batch fecundity in northern anchovy, Engraulis mordax. Fish. Bull. 77:641-652.

Jespersen,

1984. Spermatozoans from a parasitic dwarf male of Neoceratias spinifer Pappenheim, 1914. Vidensk. Medd. Dan. Nathist. Foren. 145:37-42.

Koslow, J. A., J. Bell, P. Virtue, and D. C. Smith.

1995. Fecundity and its variability in orange roughy: effects of population density, condition, egg size, and senescence. J. Fish Biol. 47:1063-1080. Article

Koslow, J. A., G. W. Boehlert, J. D. M. Gordon, R. L. Haedrich, P. Lorance, and N. Parin.

(northeastern Mediterranean). Hydrobiologia 440:281-296. 2000. Continental slope and deep-sea fisheries: implications for a fragile ecosystem. ICES J. Mar. Sci. 57:548-557. Article

Labropoulou, M., and C. Papaconstantinou.

2000. Community structure of deep-sea demersal fish in the North Aegean Sea. Hydrobiologia 440:281-296. Article

Lahnsteiner, F., and R. A. Patzner.

1990. Spermiogenesis and structure of mature spermatozoa in blenniid fishes (Pisces, Blenniidae). J. Submicros. Cytol. Pathol. 22:565-576.

Lehodey, P., R. Grandperrin, and P. Marchal.

1997. Reproductive biology and ecology of a deep-demersal fish, alfonsino Beryx splendens, over the seamounts off New Caledonia. Mar. Biol. 128:17-27. Article

Leslie, R. W., and W. S. Grant.

1990. Lack of congruence between genetic and morphological stock structure of the southern African anglerfish Lophius vomerinus. S. Afr. J. Mar. Sci. 9:379-389. Article

López, N., J. Navarro, C. Barría, M. Albo-Puigserver, M. Coll, and I. Palomera.

2016. Feeding ecology of two demersal opportunistic predators coexisting in the northwestern Mediterranean Sea. Est. Coast. Shelf Sci. 175:15-23. Article

Maartens, L., and A. J. Booth.

2005. Aspects of the reproductive biology of monkfish
Lophius vomerinus off Namibia. Afr. J. Mar. Sci. 27:325-330. Article

Maiorano, P., L. Sion, R. Carlucci, F. Capezzuto, A. Giove, G. Costantino, M. Panza, G. D’Onghia, and A. Tursi.

2010. The demersal faunal assemblage of the north-western Ionian Sea (central Mediterranean): current knowledge and perspectives. Chem. Ecol. 26:219-240. Article

Manni, L., and M. B. Rasotto.

1997. Ultrastructure and histochemistry of the testicular efferent duct system and spermiogenesis in Opistognathus whitehurstii (Teleostei, Trachinoidei). Zoomorphology 117:93-102. Article

Mattei, C., and X. Mattei.

1978. La spermiogenèse d'un poisson téléostéen (Lepadogaster lepadogaster). II. Le spermatozoïde. Biol. Cell. 32:267-274.

Mattei, X., Y. Siau, O. T. Thiaw, and D. Thiam.

1993. Peculiarities in the organization of testis of Ophidion $s p$. (Pisces Teleostei). Evidence for two types of spermatogenesis in teleost fish. J. Fish Biol. 43:931-937. Article

Merrett, N. R.

1994. Reproduction in the North Atlantic oceanic ichthyofauna and the relationship between fecundity and species' sizes. Environ. Biol. Fish. 41:207-245. Article

Morales-Nin, B., E. Massutí, and C. Stefanescu.

1996. Distribution and biology of Alepocephalus rostratus from the Mediterranean Sea. J. Fish Biol. 48:1097-1112. Article

Morato, T., R. Watson, T. J. Pitcher, and D. Pauly. 2006. Fishing down the deep. Fish Fish. 7:24-34. Article

Muñoz, M., M. Casadevall, and S. Bonet.

2002. Testicular structure and semicystic spermatogenesis in a specialized ovuliparous species: Scorpaena notata (Pisces, Scorpaenidae). Acta Zool. 83:213-219. Article

Muñoz, M., C. Dimitriadis, M. Casadevall, S. Vila, E. Delgado, J. Lloret, and F. Saborido-Rey.

2010. Female reproductive biology of the bluemouth Helicolenus dactylopterus dactylopterus: spawning and fecundity. J. Fish Biol. 77:2423-2442. Article

Murua, H., and F. Saborido-Rey.

2003. Female reproductive strategies of marine fish species of the North Atlantic. J. Northwest Atl. Fish. Sci 33:23-31. Article

Murua, H., G. Kraus, F. Saborido-Rey, P. R. Witthames, A. Thorsen, and S. Junquera.

2003. Procedures to estimate fecundity of marine fish species in relation to their reproductive strategy. J. Northwest Atl. Fish. Sci. 33:33-54. Article

Nash, R. D. M., P. R. Witthames, M. Pawson, and E. Alesworth. 2000. Regional variability in the dynamics of reproduction and growth of Irish Sea plaice, Pleuronectes platessa L. J. Sea Res. 44:55-64. Article

Negzaoui-Garali, N., and M. Ben Salem.

2008. Morphological characters and meristic counts in two anglerfishes, Lophius budegassa and L. piscatorius (Osteichthyes: Lophiidae) from Tunisian coastal waters (central Mediterranean). Ann. Ser. Hist. Nat. 18:17-26.

Nissling, A., and G. Dahlman.

2010. Fecundity of flounder, Pleuronectes flesus, in the Baltic Sea-reproductive strategies in two sympatric populations. J. Sea Res. 64:190-198. Article

Norse, E. A., S. Brooke, W. W. L. Cheung, M. R. Clark, I. Ekeland, R. Froese, K. M. Gjerde, R. L. Haedrich, S. S. Heppell, T. Morato, et al.

2012. Sustainability of deep-sea fisheries. Mar. Policy 36:307-320. Article 
Pajuelo, J. G., J. M. Lorenzo, and R. Dominguez-Seoane. 2008. Gonadal development and spawning cycle in the digynic hermaphrodite sharpsnout seabream Diplodus puntazzo (Sparidae) off the Canary Islands, northwest of Africa. J. Appl. Ichthyol. 24:68-76. Article

Pavlov, D. A., N. G. Emel'yanova, and G. G. Novikov.

2009. Reproductive dynamics. In Fish reproductive biology: implications for assessment and management ( $\mathrm{T}$. Jakobsen, M. J. Fogarty, B. A. Megrey, and E. Moksness, eds.), p. 48-90. Wiley-Blackwell, Oxford, UK.

Pianka, E. R.

1970. On r- and K-selection. Am. Nat. 104:592-597. Article 1974. Niche overlap and diffuse competition. Proc. Natl. Acad. Sci. U.S.A. 71:2141-2145. Article

Ramirez-Llodra, E., A. Brandt, R. Danovaro, B. De Mol, E. Escobar, C. R. German, L. A. Levin, P. M. Arbizu, L. Menot, P. Buhl-Mortensen, B. E. Narayanaswamy, C. R. Smith, D. P. Tittensor, P. A. Tyler, A. Vanreusel, and M. Vecchione.

2010. Deep, diverse and definitely different: unique attributes of the world's largest ecosystem. Biogeosciences 7:2851-2899. Article

Ramirez-Llodra, E., P. A. Tyler, M. C. Baker, O. A. Bergstad, M. R. Clark, E. Escobar, L. A. Levin, L. Menot, A. A. Rowden, C. R. Smith, et al.

2011. Man and the last great wilderness: human impact on the deep sea. PLoS ONE 6(8):e22588. Article

Recasens, L., V. Chiericoni, and P. Belcari.

2008. Spawning pattern and batch fecundity of the European hake (Merluccius merluccius (Linnaeus, 1758)) in the western Mediterranean. Sci. Mar. 72:721-732. Article

Rotllant, G., J. Moranta, E. Massutí, F. Sarda, and B. Morales-Nin.

2002. Reproductive biology of three gadiform fish species through the Mediterranean deep-sea range (147-1850 m). Sci. Mar. 66:157-166. Article

Sàbat, M., F. Lo Nostro, M. Casadevall, and M. Muñoz.

2009. A light and electron microscopic study on the organization of the testis and the semicystic spermatogenesis of the genus Scorpaena (Teleostei, Scorpaenidae). J. Morphol. 270:662-672. Article

Sedberry, G. R., J. L. Carlin, R. W. Chapman, and B. Eleby. 1996. Population structure in the pan-oceanic wreckfish, Polyprion americanus (Teleostei: Polyprionidae), as indicated by mtDNA variation. J. Fish Biol. 49:318-329. Article

Stearns, S. C., and J. C. Koella.

1986. The evolution of phenotypic plasticity in life-history traits: predictions of reaction norms for age and size at maturity. Evolution 40:893-913.

Stewart, J., K. Rowling, A.-M. Hegarty, and A. Nuttall.

2010. Size and age at sexual maturity of snapper Pagrus auratus in New South Wales 2008/09, 38 p. Industry \& Investment NSW, Cronulla, North South Wales, Australia.

Thorsen, A., P. R. Witthames, G. Marteinsdóttir, R. D. M. Nash, and O. S. Kjesbu.

2010. Fecundity and growth of Atlantic cod (Gadus morhua L.) along a latitudinal gradient. Fish. Res. 104:45-55. Article

Treasurer, J. W.

1981. Some aspects of the reproductive biology of perch
Perca fluviatilis L. Fecundity, maturation and spawning behaviour. J. Fish Biol. 18:729-740. Article

Tsimenidis, $\mathrm{N}$.

1984. The growth pattern of otoliths of Lophius piscatorius L., 1758 and Lophius budegassa Spinola, 1807 in the Aegean Sea. Cybium 8:35-42.

Tsimenidis, N. C., and J. C. Ondrias.

1980. Growth studies on the angler-fishes Lophius piscatorius L., 1758 and Lophius budegassa Spinola, 1807 in Greek waters. Thalassografika 3:63-94.

Ungaro, N., G. Marano, R. Auteri, A. Voliani, E. Massutí, M. García-Rodríguez, and K. Osmani.

2002. Distribution, abundance and biological features of anglerfish (Lophius piscatorius and Lophius budegassa) (Osteichthyes: Lophiiformes) in the Mediterranean Sea. Sci. Mar. 66:55-63.

Valentim, M. F. M., E. P. Caramaschi, and M. Vianna.

2007. Biology and ecology of anglerfishes of the genus Lophius (Lophiidae, Lophiiformes) with emphasis in Lophius gastrophysus Miranda-Ribeiro, 1915: current status. Oecol. Bras. 11:503-520.

Valls, M., C. J. Sweeting, M. P. Olivar, M. L. Fernández de Puelles, C. Pasqual, N. V. C. Polunin, and A. Quetglas.

2014. Structure and dynamics of food webs in the water column on shelf and slope grounds of the western Mediterranean. J. Marine Syst. 138:171-181. Article

van Overzee, H. M. J., and A. D. Rijnsdorp.

2015. Effects of fishing during the spawning period: implications for sustainable management. Rev. Fish Biol. Fish. 25:65-83. Article

Walmsley, S. A., R. W. Leslie, and W. H. H. Sauer.

2005. The biology and distribution of the monkfish Lophius vomerinus off South Africa. Afr. J. Mar. Sci. 27:157-168. Article

Wallace, R. A., and K. Selman.

1981. Cellular and dynamic aspects of oocyte growth in teleosts. Am. Zool. 21:325-343. Article

Watson, R. A., and T. Morato.

2013. Fishing down the deep: accounting for within-species changes in depth of fishing. Fish. Res. 140:63-65. Article

West, G.

1990. Methods of assessing ovarian development in fishes: a review. Aust. J. Mar. Freshw. Res. 41:199-222. Article

Yoneda, M., M. Tokimura, H. Fujita, N. Takeshita, K. Takeshita, M. Matsuyama, and S. Matsuura.

1997. Age and growth of anglerfish Lophius litulon in the East China Sea and the Yellow Sea. Fish. Sci. 63:887-892.

1998. Reproductive cycle and sexual maturity of the anglerfish Lophiomus setigerus in the East China Sea with a note on specialized spermatogenesis. J. Fish Biol. 53:164-178. Article

2001. Reproductive cycle, fecundity, and seasonal distribution of the anglerfish Lophius litulon in the East China and Yellow seas. Fish. Bull. 99:356-370.

Yoneda, M., M. Tokimura, H. Horikawa, K. Yamamoto, M. Matsuyama, and S. Matsuura.

2002. Spawning migration of the anglerfish Lophius litulon in the East China and Yellow Seas. Fish. Sci. 68:310-313. 